Pesq. Vet. Bras. 38(2):315-319, fevereiro 2018

\title{
Combination of Transversus abdominis plane block and Serratus plane block anesthesia in dogs submitted to masctetomy ${ }^{1}$
}

\author{
Luciana G. Teixeira ${ }^{2 *}$, Diego M. Pujol², Aline F. Pazzim², \\ Renata P. Souza ${ }^{2}$ and Leandro Fadel ${ }^{3}$
}

\begin{abstract}
Teixeira L.G., Pujol M.D., Pazzim F.A., Souza R.P. \& Fadel L. 2018. Combination of Transversus abdominis plane block and Serratus plane block anesthesia in dogs submitted to masctetomy. Pesquisa Veterinária Brasileira 38(2):315-319. Hospital Veterinário, Universidade Luterana do Brasil, Av. Farroupilha 8001, São José, Canoas, RS 92425-900, Brazil. E-mail: lucianateixeira@gmail.com

This paper pretends to demonstrate the effect of the combination of transversus abdominis plane block (TAP block) and Serratus plane block (SP block) techniques in analgesia of 4 dogs undergoing total unilateral mastectomy. Dogs were premedicated with methadone $\left(0.5 \mathrm{mg} \cdot \mathrm{kg}^{-1}\right)$ intramuscularly. Anesthesia was induced with propofol $\left(6 \mathrm{mg} \cdot \mathrm{kg}^{-1}\right)$ and midazolam $\left(0.3 \mathrm{mg}^{\mathrm{kg}}{ }^{-1}\right)$ and maintained with isoflurane. SP and TAP block were performed unilaterally using ultrasound by the injection of bupivacaine $0.25 \%\left(0.3 \mathrm{~mL} \mathrm{~kg}^{-1}\right)$ diluted with $\mathrm{NaCl}$ solution 1:1. Heart rate (HR), respiratory rate ( $f$ ), non-invasive arterial pressure, esophageal temperature (T), oxygen saturation (Sp02) and electrocardiogram were monitored continuously. Animals were monitored for two and four hours after extubation for pain by using the Canine Acute Pain Scale from Colorado State University. Two hours after extubation, tramadol (4mg.kg-1) and dipyrone (25mg. $\mathrm{kg}^{-1}$ ) was administered to all dogs. It was not observed any alteration on cardiac rhythm. HR, $f$, T and mean arterial pressure remained below the preincisional values for all dogs. No dog required intraoperative rescue analgesia. Recovery from anesthesia was without any complication. All animals scored $0(0 / 5)$ at pain scale, two and four hours after extubation and none of them expressed concern over the surgical wound. Dogs were able to walk before two hours after extubation. The combination of both techniques is effective in anesthetic blocking the thoracic and abdominal walls and it is suggested both may be included in the multimodal analgesia protocols for this type of surgery.

INDEX TERMS: Transversus abdominis plane block anesthesia, Locorregional anesthesia, TAP block, Serratus plane block, dog, surgery.
\end{abstract}

RESUMO.- [Combinação dos bloqueios anestésicos do plano transverso abdominal e do plano serrátil em cadelas submetidas à mastectomia.] Este trabalho pretende demonstrar o efeito analgésico da combinação das técnicas de bloqueio do plano transverso abdominal (TAP block) e bloqueio do plano serrátil (SP block) em 4 cadelas submetidas à mastectomia unilateral total. Os animais foram pré-medicados

\footnotetext{
${ }^{1}$ Received on September 12, 2016. Accepted for publication on December 9, 2016.

${ }^{2}$ Hospital Veterinário, Universidade Luterana do Brasil, Av. Farroupilha 8001, São José, Canoas, RS 92425-900, Brazil. *Corresponding author: lucianateixeira@gmail.com

${ }^{3}$ Universidade Luterana do Brasil, Av. Farroupilha 8001, São José, Canoas, RS 92425-900, Brazil.
}

com metadona $\left(0,5 \mathrm{mg}_{\mathrm{kg}}{ }^{-1}\right)$ por via intramuscular. A anestesia foi induzida com propofol $\left(6 \mathrm{mg} \cdot \mathrm{kg}^{-1}\right)$ e midazolam $\left(0,3 \mathrm{mg} \cdot \mathrm{kg}^{-1}\right)$ e mantida com isoflurano. Os bloqueios SP e TAP foram realizados unilateralmente, utilizando ultrassonografia, pela injeção de bupivacaína a $0,25 \%\left(0,3 \mathrm{~mL} \cdot \mathrm{kg}^{-1}\right)$, diluída com solução de $\mathrm{NaCl}$ a 1:1. A frequência cardíaca (FC), frequência respiratória (f), pressão arterial não invasiva, temperatura esofágica (T), saturação de oxigênio (SpO2) e eletrocardiograma foram monitorados continuamente. Os animais foram monitorizados durante duras e quatro horas após a extubação para a dor usando a Escala de Dor Aguda Canina da Universidade Estadual do Colorado. Duas horas após a extubação, tramadol (4mg.kg-1) e dipirona (25mg. $\left.\mathrm{kg}^{-1}\right)$ foram administrados a todos os cães. Não foi observada qualquer alteração no ritmo cardíaco. 
HR, f, T e pressão arterial média permaneceram abaixo dos valores basais para todos os cães. Nenhum cão requereu resgate analgésico intra-operatório. Não houve complicações na recuperação anestésica. Todos os animais apresentaram escore $0(0 / 5)$ na escala de dor, duras e 4 quatrohoras após a extubação e nenhum expressou desconforto com a ferida cirúrgica. Todos os cães foram capazes de caminhar antes de duas horas após extubação. A combinação de ambas as técnicas é eficaz no bloqueio anestésico das paredes torácica e abdominal e sugere-se que ambos podem ser incluídos nos protocolos de analgesia multimodal para este tipo de cirurgia.

TERMOS DE INDEXAÇÃO: Anestesia locorregional, TAP block, bloqueio do plano serrátil, cadela, cirurgia.

\section{INTRODUCTION}

Mammary tumors are the most prevalent cancer among dogs, to which the gold standard treatment is surgery (Dantas Cassali et al. 2012). Since dogs have a mammary chain comprising 5 udder and, in most cases, the tumors affect over a gland, such animals are subjected to a considered severe pain surgery which is extensive, involving skin, subcutaneous tissue and even muscles, and can promote stress during and after the procedure.

As a condition often malignant and that mostly affects elderly patients, it is necessary to find techniques that are appropriate to the anesthetic risks, which are larger in this type of patient due to typically have a lower reserve of physiological various organ systems and the effects of pathophysiological disorders arising from metastasis or paraneoplastic syndrome that these individuals present (Salazar 2014). As geriatric and / or cancer patients are classified as hazardous, there is a search towards decreasing the amount of general anesthetics and analgesics are to be used. The locoregional anesthesia prevents altogether, the transmission of nociceptive impulse and produces satisfactory analgesia for risk patients as often allows reduce opioid requirement and general anesthetics required for optimal surgical plane of anesthesia (Lemke \& Dawson 2000).

The transversus abdominis plane block (TAP block) is described as a technique capable of blocking the abdominal wall by the injection of local anesthetic between the muscle fascia of abdominal internal oblique and transverse abdominal muscles, using an ultrasound probe (Rafi 2001, Taylor et al. 2013). In 2015, De La Torre et al. (2014) presented a new regional anesthetic technique guided by ultrasound for breast surgery analgesia in women. This technique is a variation of the TAP block and involves the injection of the drug between the serratus anterior and external intercostal muscle. According to the authors, this technique is an alternative to the intercostal nerves blockage which, as in veterinary medicine, is performed blindly and requires multiple punctures. In medicine, TAP block has been used successfully in a wide variety of surgical procedures. In veterinary medicine, however, these techniques have yet been little reported.

The aim of this work is to demonstrate the combination of transversus abdominis plane block and Serratus plane block (SP block) techniques in dogs undergoing total unilateral mastectomy and present the results obtained during 2 and 4 hours after surgery.

\section{MATERIALS AND METHODS}

Four female dogs of different breeds, aging between eight and 10 years old and weighing 6,3 to $27 \mathrm{~kg}$ were attented at the Hospital Veterinário da Universidade Luterana do Brasil (HV-ULBRA) with a history of mammary tumor over a year and were referred to surgery of radical unilateral mastectomy. Physical examination, total blood count and serum biochemistry profile and imaging exams in search of metastasis were performed in all dogs prior to the surgery. Three dogs were classified as ASA II and one as ASA III. Food and water were withheld 12 and 2 hours prior surgery, respectively.

All dogs received methadone $\left(0.5 \mathrm{mg} . \mathrm{kg}^{-1}\right)$ intramuscularly as anesthetic premedication and had an intravenous catheter placed in cephalic vein for drugs and fluid administration. General anesthesia was induced with the combination of propofol (6mg. $\left.\mathrm{kg}^{-1}\right)$ and midazolam $\left(0.3 \mathrm{mg} \cdot \mathrm{kg}^{-1}\right)$ and the orotracheal intubation was performed. The endotracheal tube was connected to a rebreathing system and oxygen at 100\% was delivered. General anesthesia was maintained with isoflurane between 1 to $2.5 \mathrm{~V} \%$. Warmed lactated Ringer's solution was administered ( 2 to $5 \mathrm{~mL} . \mathrm{kg}^{-1}$ hour-1 IV) throughout the procedure.

To perform SP block and TAP block dogs were laid in lateral decubitus with the side to be blocked uppermost and the entire thoracic and abdominal walls were clipped and the skin antisepsis was made. Techniques were performed as described by Schroeder et al. (2011) and De La Torre et al. (2014). The ultrasound probe (11 MHz frequency probe connected to a General Eletric Logiq 500 Ultrasound machine) was positioned perpendicularly to the long body axis, first, at the thorax between the fourth and the nineth intercostal spaces, respectively, where 3 muscles fascias were identified (latissimus dorsi muscle, serratus ventralis muscle and external intercostal muscle) (Fig.1a). A spinal needle (22 gauge) connected to a syringe containing the anesthetic was introduced with a dorso-ventral direction between serratus ventralis muscle and external intercostal muscle (Fig.1b). The correct position of the needle was identified by the real time ultrasound image and the solution containing bupivacaine $0.25 \%\left(0.3 \mathrm{~mL} \mathrm{~kg}^{-1}\right)$ diluted in saline solution (1:1) was injected (Fig.2). In order to perform TAP block, similar procedure was conducted in the abdomen in two different points, caudally to the last rib and cranially to the iliac crest. The anesthetic was, then, injected between internal oblique and transverse muscles of the abdomen, identified by ultrasound image. In all four anesthetic blocks, the anesthetic injections caused the separation of the muscle layers.

Throughout the entire anesthetic procedure, heart rate (HR), respiratory rate $\left(f_{R}\right)$, non-invasive arterial pressure (mean, diastolic and systolic), esophageal temperature, oxygen saturation ( $\mathrm{SpO}_{2}$ ) and electrocardiogram (leads II, III and aVF) were monitored continuously and recorded every 10 minutes using a multiparametric monitor. Fentanyl $\left(3 \mu \mathrm{g} \cdot \mathrm{kg}^{-1}, \mathrm{IV}\right)$ would be administered to every dog presenting an increase above $20 \%$ of the preincisional values for heart rate or mean arterial pressure, which would be admitted as nociceptive response.

After surgery, meloxicam $\left(0.2 \mathrm{mg} . \mathrm{kg}^{-1}\right)$ was administered, intravenously, to all dogs and they were monitored for 2 and 4 hours after extubation for pain by using the Canine Acute Pain Scale from Colorado State University which establishes 5 scores for pain (0 to 4), being 0 considered minimal and 4, severe pain. At the evaluation of the second hour after extubation, tramadol (4mg. $\mathrm{kg}^{-1}$ ) and dipyrone (25mg. $\mathrm{kg}^{-1}$ ) were administered to all dogs. Analgesic rescue would be done if the dog scored over 2 points. 


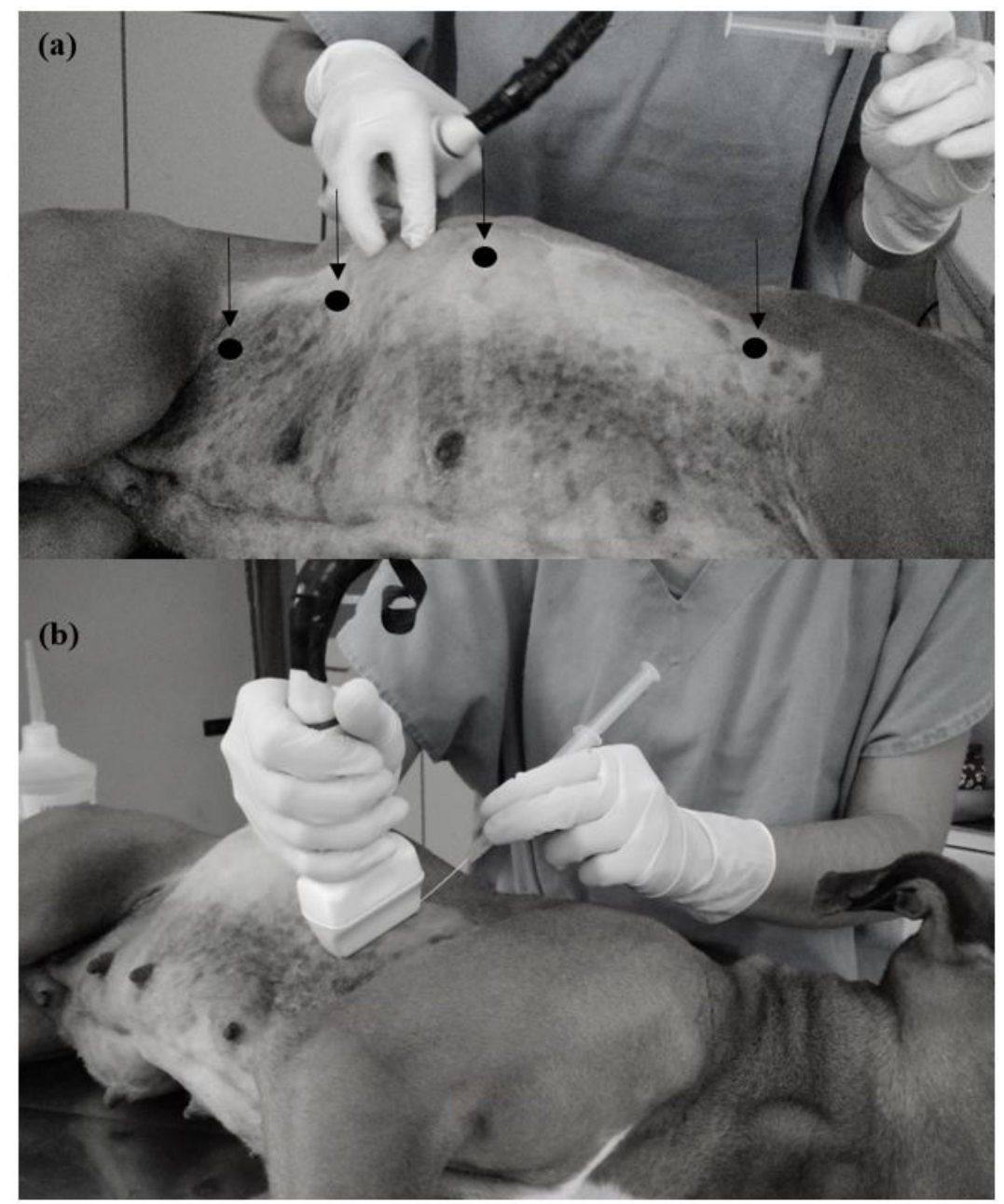

Fig.1. (a) Representation of the points of ultrasound transducer positioning and direction of the needle to perform Serratus plane block (the fourth and the nineth intercostal spaces) and TAP block (in the caudal and cranial abdomen). (b) Perfomance of Serratus plane block, introducing a spinal needle perpendicularly to the long axis, at the fourth intercostal space.

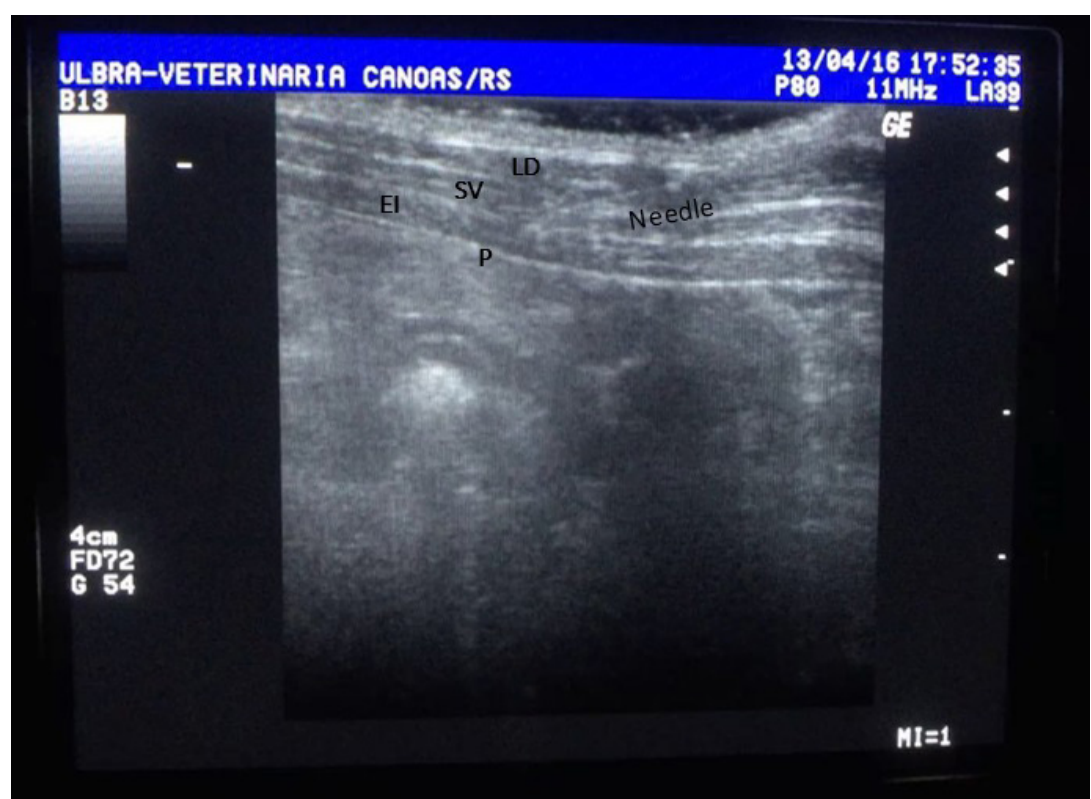

Fig.2. Ultrasonographic image of muscular layers of thorax wall and the needle being introduced in the serratus plane. LD $=$ latissimus dorsi muscle, $\mathrm{SV}=$ serratus ventralis muscle, $\mathrm{EI}=$ external intercostal muscle, $\mathrm{P}=$ parietal pleura. 


\section{RESULTS}

The total median time of procedure was 88 minutes (range: 29 minutes). For all dogs, isoflurane was maintained below 1,9 vol\% (median: 1.84 , range: 0.6 ). It was not observed any alteration on cardiac rhythm during all the procedure and heart rate and respiratory rate remained relatively constant for each animal during surgery, being always below baseline values for each animal. Mean arterial pressure ranged between 55 and $96 \mathrm{mmHg}$. During surgery parameters evaluated remained below the preincisional values for all dogs. Vasoactive drugs or anticholinergic for supporting cardiovascular function were not required. No dog required intraoperative rescue analgesia.

The median time for discharging dogs from the operation room was 12 minutes (range: 4 minutes). Recovery from anesthesia was smooth and without any complication for all dogs. All animals scored 0 at the both times pain was assessed, two and four hours after extubation. At the first evaluation, two hours after extubation, tramadol (4mg.kg-1 intramuscularly) and dipyrone (25 mg. $\mathrm{kg}^{-1}$ intramuscularly) was administered to all dogs. Three of four dogs showed minimal tension to palpation of wound zone and none of them expressed concern over the surgical wound at both assessments. Before the second hour after extubation all dogs were able to walk unassisted and to eat. All dogs were discharged home between six and 12 hours after surgery with adequately care recommendations. No complications related to the anesthetic or surgical procedure were observed in the follow-up of every dog.

\section{DISCUSSION}

Transversus abdominis plane block has been used quite successfully in human medicine. Schroeder et al. (2011) described technique in veterinary medicine for the first time. The authors conducted an anatomical assessment of technical injecting $10 \mathrm{ml}$ of solution with methylene blue and bupivacaine in the fascial plane between the internal oblique and transverse muscles of the abdomen beagle dog cadavers and verified the spreading of the methylene blue solution overlapping the transverse abdominal muscle, effectively dyeing branches T12, T13, L1 and L2 at frequencies of 60, 100,100 and $90 \%$ respectively.

Studies have shown the sensory blockade of various dermatomes for up to 24 hours (Taylor et al. 2013). In a meta-analysis of 5 studies of analgesia promoted by performing TAP block in hysterectomies after surgery in women, Champaneria et al. (2013) concluded that the technique diminishes pain levels both at rest and in motion after surgery for 24 hours. Sharkey et al. (2013) reported a number of studies demonstrating significant decrease in morphine consumption by people who received TAP block and suggested that there is clear evidence that the transverse abdominis plane block confer analgesic benefit when used as part of a multimodal analgesic plane.

Besides the use in open abdominal surgery, TAP block has also been widely used to promote postoperative analgesia in breast reconstruction procedures with surgical techniques involving the resection of a large part of the skin, subcutaneous tissue and even muscle of the abdomen and thus causing severe pain. According to Hivelin et al. (2011) and Wheble et al. (2013), the groups that received the TAP block for this type of procedure required statistically less opioid within 24 hours after surgery, showed less postoperative nausea and vomiting and reduced hospital stay. Blanco et al. (2013) and De La Torre et al. (2014) showed a variation of the technique for thoracic surgery, focusing on analgesia for performing mastectomy in which the anesthetic is thought to spread from T2 to T6. In Serratus Plane block the deposition of local anesthetic, which is guided by ultrasound, occurs between the fascia of the anterior serratus and external intercostal muscles.

The abdominal wall, peritoneum and abdominal mammary glands of the dogs are innervated by nerves of the lateral branches from T11 to L3, which can be adequately blocked by TAP block and subcostal TAP block, described by Hebbard (2008), while thoracic mammary glands receive innervation from the lateral or ventral cutaneous branches derived from T3 to T7, besides ventral cutaneous branches of intercostal nerves (Evans \& de Lahunta 2013). Due to canine mammary glands innervation anatomy, it was hypothesized that TAP block combined with Serratus plane block executed in two different points in thoracic wall would be able to block effectively all the mammary chain to be resectioned.

In the present work, it was verified that the combination of two ultrasound techniques, TAP block and Serratus plane block, provided intraoperative nociception that lasted, at least, two hours after surgery for bitches submitted to unilateral radical mastectomy. During the whole period of surgery, all dogs presented heart rate, respiratory rate and median arterial pressure below the baseline values. No animal required supplemental analgesia during perioperative or short-term postoperatively. Methadone, administered to all dogs as pre-anesthetic medication is believed to have contributed to the antinociception effect of the ultrasound guided blocks as, differently of Portela et al. (2014) no sign of nociception was identified during ligation of inguinal canal structures.

Portela et al. (2014) associated TAP block and intercostal nerve block in 11 bitches submitted to unilateral radical mastectomy. Four animals required rescue analgesia in the perioperative, which was related to the failure of intercostal nerves block, since nociceptive stimuli were identified in resecting the caudal thoracic mammary glands. Comparing with the results of these authors, we believe that the Serratus plane block performed was adequate to provide perioperative analgesia and postoperative comfort, given all dogs scored 0 in both pain assessments and methadone, alone, is unlikely to provide such degree of analgesia. In woman, serratus anterior plane block is believed to ensure excellent analgesia with predictable drug spread, less invasiveness and more safety with compared with other regional anesthetic techniques for breast surgery (Bhoi et al. 2016).

Bupivacaine $0,25 \%$ diluted in saline solution $1: 1$ was used in order to increase the volume injected and the nerve branches reached by the anesthetic. The total bupivacaine dose was close to maximal dose recommended for dogs without surpassing the toxic dose (4.4mg. $\mathrm{kg}^{-1}$ ) (Tranquilli et al. 2007).

\section{CONCLUSIONS}

The objective of this study was to demonstrate that the combination of the transversus abdominis plane block and Serratus plane block is able to effectively block the abdominal and chest walls respectively, enabling the performance of unilateral radical mastectomy. 
According to our knowledge, such combination of both techniques were never reported in veterinary medicine before. It was concluded that the combination of the two techniques is effective in anesthetic blocking the thoracic and abdominal walls and it is suggested both may be included in the multimodal analgesia protocols for this type of surgical procedure.

\section{REFERENCES}

Bhoi D., Pushparajan H.K., Talawar P., Kumar A. \& Baidya D.K. 2016. Serratus anterior plane block for breast surgery in a morbidly obese patient. J. Clin. Anesth. 33:500-501. PMid:26603109. http://dx.doi.org/10.1016/j. jclinane.2015.09.004.

Blanco R., Parras T., Mcdonnell J.G. \& Prats-Galino A. 2013. Serratus plane block: a novel ultrasound-guided thoracic wall nerve block. Anaesthesia 68(11):1107-1113. PMid:23923989. http://dx.doi.org/10.1111/anae.12344.

Champaneria R., Shah L., Geoghegan J., Gupta J.K. \& Daniels J.P. 2013. European journal of obstetrics \& gynecology and reproductive biology analgesic effectiveness of transversus abdominis plane blocks after hysterectomy: a meta-analysis. Eur. J. Obstet. Gynecol. 166(1):1-9. http:// dx.doi.org/10.1016/j.ejogrb.2012.09.012.

Dantas Cassali G., Cavalheiro Bertagnolli A., Ferreira E., Araújo Damasceno K., de Oliveira Gamba C. \& Bonolo de Campos C. 2012. Canine mammary mixed tumours: a review. Vet. Med. Int. 2012:274608. PMid:23193497.

De La Torre P.A., García P.D., Alvarez S.L., Miguel F.J. \& Pérez M.F. 2014. A novel ultrasound-guided block: a promising alternative for breast analgesia. Aesthet. Surg. J. 34(1):198-200. PMid:24396082. http://dx.doi. org/10.1177/1090820X13515902.

Evans H.E. \& De Lahunta A. 2013. Miller's anatomy of the dog. 4th ed. Elsevier, St louis. 872p.

Hebbard P. 2008. Subcostal transversus abdominis plane block under ultrasound guidance. [letter]. Anesth. Analg. 106(2):674-675, author reply 675. PMid:18227342. http://dx.doi.org/10.1213/ane.0b013e318161a88f.
Hivelin M., Wyniecki A., Plaud B., Marty J. \& Lantieri L. 2011. Ultrasound-guided bilateral transversus abdominis plane block for postoperative analgesia after breast reconstruction by diep flap. Plast. Reconstr. Surg. 128(1):4455. PMid:21701318. http://dx.doi.org/10.1097/PRS.0b013e3182174090.

Lemke K.A. \& Dawson S.D. 2000. Local and regional anesthesia. Vet. Clin. N. Am. Small Anim. Pract. 30(4):839-857. http://dx.doi.org/10.1016/ S0195-5616(08)70010-X.

Portela D.A., Romano M. \& Briganti A. 2014. Retrospective clinical evaluation of ultrasound guided transverse abdominis plane block in dogs undergoing mastectomy. Vet. Anaesth. Analg. 41(3):319-324. PMid:24754569. http:// dx.doi.org/10.1111/vaa.12122.

Rafi A.N. 2001. Abdominal field block: a new approach via the lumbar triangle. Anaesthesia 56(10):1024-1026. PMid:11576144.http://dx.doi. org/10.1046/j.1365-2044.2001.02279-40.x.

Schroeder C.A., Snyder L.B.C., Tearney C.C., Baker-Herman T.L. \& Schroeder K.M. 2011. Ultrasound-guided transversus abdominis plane block in the dog: an anatomical evaluation. Vet. Anaesth. Analg. 38(3):267-271. PMid:21492393. http://dx.doi.org/10.1111/j.1467-2995.2011.00612.x.

Sharkey A., Finnerty 0. \& McDonnell J.G. 2013. Transversus abdominis plane block. Curr. Anesthesiol. Rep. 3(4):223-229. PMid:23587731. http://dx.doi. org/10.1007/s40140-013-0034-5.

Taylor R.Jr, Pergolizzi J.V., Sinclair A., Raffa R.B., Aldington D., Plavin S. \& Apfel C.C. 2013. Transversus abdominis block: clinical uses, side effects, and future perspectives. Pain Pract. 13(4):332-344. PMid:22967210. http:// dx.doi.org/10.1111/j.1533-2500.2012.00595.x.

Tranquilli W.J., Thurmon J.C. \& Grimm K.A. 2007. Lumb and jones' veterinary anesthesia and analgesia. Blackwell Publishing, 1096p.

Salazar V. 2014. Neoplastic disease, p.264-298. in: Snyder l.B.C. \& Johnson R.A. (eds), Canine and feline anesthesia and co-existing disease. John Wiley and Sons Inc., Hoboken, NJ, USA.

Wheble G.A., Tan E.K., Turner M., Durrant C.A. \& Heppell S. 2013. Surgeonadministered, intra-operative transversus abdominis plane block in autologous breast reconstruction: an UK hospital experience. J. Plast. Reconstr. Aesthet. Surg. 66(12):1665-1670. PMid:23910912. http://dx.doi. org/10.1016/j.bjps.2013.07.017. 